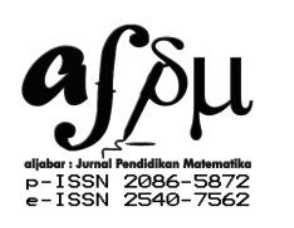

\title{
Pembelajaran Konflik Kognitif Untuk Meningkatkan Kemampuan Komunikasi Matematis Siswa Berdasarkan Kategori Pengetahuan Awal Matematis
}

\author{
Rizki Wahyu Yunian Putra \\ IAIN Raden Intan Lampung: rizkiputra8916@yahoo.com \\ Submitted : 16-10-2015, Revised : 18-11-2015, Accepted :16-12-2015
}

\begin{abstract}
The ability of mathematical communication is a competence that must be owned by students, but the reality in the field shows that the ability of mathematical communication is still not satisfactory. Cognitive conflict learning is applied in the hope of improving students' mathematical communication skills. The purpose of this study is to examine the improvement of students' mathematical communication skills that apply cognitive conflict learning and ordinary learning, to examine differences in the improvement of mathematical communication skills of students applying cognitive conflict learning and students who received regular learning when viewed from the early knowledge category of mathematics (high and low ). This research is a quasi experiment or quasi experiment with non-equivalent control group design. The implementation of this research was conducted on XIPA class students in one of the Private High Schools in Bandung. Problems given are questions of mathematical communication ability in trigonometric material, test of mathematical communication ability test is tested theoretically by validator with picture that test question can be well understood and empirically validity and reliability meet the characteristics to be used in research, Difficulties and distinguishing matters have been able to distinguish highability students and low-ability students. Quantitative data analysis was performed by using the difference test and the two-track Anova test. The results of this study are students whose learning applying cognitive conflict learning improves the ability of mathematical communication is significantly better than that of students whose learning using ordinary learning is reviewed in whole.
\end{abstract}

Keywords: Communication; Cognitive; Conflict; Mathematical.

\begin{abstract}
Abstrak
Kemampuan komunikasi matematis merupakan kompetensi yang harus dimiliki siswa, namun kenyataan di lapangan menunjukkan bahwa kemampuan komunikasi matematis masih belum memuaskan. Pembelajaran konflik kognitif diterapkan dengan harapan untuk meningkatkan kemampuan komunikasi matematis siswa. Tujuan pada penelitian ini adalah untuk menelaah peningkatan kemampuan komunikasi matematis siswa yang menerapkan pembelajaran konflik kognitif dan pembelajaran biasa, mengkaji perbedaan peningkatan kemampuan komunikasi matematis siswa yang menerapkan pembelajaran konflik kognitif dan siswa yang mendapat pembelajaran biasa bila ditinjau dari kategori pengetahuan awal matematika (tinggi dan rendah).
\end{abstract}


Penelitian ini merupakan penelitian quasi experiment atau eksperimen semu dengan desain kelompok kontrol non-ekuivalen. Pelaksanaan penelitian ini dilakukan pada siswa kelas XIPA di salah satu SMA Swasta di Bandung. Soal-soal yang diberikan adalah soal-soal kemampuan komunikasi matematis pada materi trigonometri, uji coba tes kemampuan komunikasi matematis diuji secara teoritik oleh validator dengan gambaran bahwa soal tes dapat dipahami dengan baik dan secara empirik validitas dan reliabilitas memenuhi karakteristik untuk digunakan dalam penelitian, tingkat kesukaran dan daya pembeda soal sudah bisa membedakan siswa berkemampuan tinggi dan siswa berkemampuan rendah. Analisis data kuantitatif dilakukan dengan menggunakan uji perbedaan rataan dan uji Anova dua jalur. Hasil penelitian ini adalah siswa yang pembelajarannya menerapkan pembelajaran konflik kognitif peningkatan kemampuan komunikasi matematis secara signifikan lebih baik dibandingkan dengan siswa yang pembelajarannya menggunakan pembelajaran biasa ditinjau secara keselurahan.

Kata kunci: Komunikasi; Konflik; Kognitif; Matematis.

\section{PENDAHULUAN}

Rendahnya mutu pendidikan di Indonesia dapat terlihat dari hasil survey Trends International Mathematics and Science study (TIMMS) (Wardhani \& Rumiati, 2011), pada tahun 2003 Indonesia berada di peringkat 34 dari 45 negara. Prestasi belajar pada TIMMS 2007 lebih memprihatinkan lagi, karena rerata skor turun dari 411 menjadi 397, jauh lebih redah dibanding rerata skor internasional yaitu 500. Prestasi Indonesia pada TIMMS 2007 berada di peringkat 36 dari 49 negara.

Tidak jauh berbeda dari hasil survey TIMMS, laporan hasil studi Programme For International Student Assesment (PISA) pada tahun 2003 melaporkan bahwa kemampuan literasi matematis siswa Indonesia di ajang PISA berada pada peringkat ke - 38 dari 39 negara yang ikut serta dalam studi tersebut. Pada tahun 2006 peringkat Indonesia berada pada peringkat ke - 51 dari 57 negara. Laporan PISA 2009 juga cenderung sama dengan tahun 2003 dan 2006 yang memperlihatkan bahwa peringkat Indonesia berada pada peringkat ke - 60 dari 64 negara. Kemampuan literasi matematis siswa Indonesia di ajang PISA berada di kelompok bawah dari seluruh Negara peserta. Literasi matematis diartikan sebagai kemampuan siswa dalam analisis, penalaran, dan komunkasi secara efektif pada saat menampilkan, memecahkan dan merepresentsikan masalah-masalah matematis (Prabawanto, 2013:4).

Soa-soal yang disajikan pada TIMMS dan PISA, kemampuan matematis siswa yang banyak diungkap diantaranya kemampuan komunikasi matematis siswa. Dapat dikatakan bahwa rendahnya kemampuan matematis siswa Indonesia banyak terletak pada aspek kemampuan komunikasi matematis.

Kondisi di sekolah-sekolah, sebagian besar siswa tampak mengkuti dengan baik setiap penjelasan dari guru, siswa sangat jarang mengajuan pertanyaan pada guru sehingga guru asyik sendiri menjelaskan apa yang telah disampaikan oleh guru (Wahyudin, 1999). Hasil studi Sumarmo (1993) terhadap siswa SMU, SLTP dan guru Kodya Bandung menemukan antara lain pembelajaran matematika pada umumnya kurang melibatkan aktifitas siswa secara optimal sehingga siswa kurang aktif dalam belajar. 
Pembelajaran yang berpusat pada guru tidak menempatkan siswa sebagai subjek didik yang menemukan pengetahuanya, melainkan sebagai objek yang harus disuapi pengetahuan, pendapat yang sama juga dikemukakan oleh Darhim (2004). Menurut Herman (2006), pembelajaran seperti ini tidak mengakomodasi pengembangan kemampuan siswa dalam pemecahan masalah, penalaran, koneksi dan komunikasi matematis. Suryadi (2005) menyatakan bahwa sebagian besar pembelajaran matematika belum berfokus pada pengembangan kemampuan pemecahan masalah, kemampuan komunikasi matematis atau kemampuan berfikir logis.

Sangat dibutuhkan pembelajaran yang tepat untuk mengakomodasi peningkatan kompetensi siswa sehingga hasil belajar dapat lebih baik khususnya kemampuan komunikasi matematis, salah satunya pembelajaran konflik kognitif. Pembelajaran konflik kognitif dapat mengkondisikan siswa untuk berfikir ke tahapan yang lebih tinggi.

Piaget dalam (Ismaimuza, 2010) menyatakan bahwa suatu struktur kognitif (struktur pengetahuan yang terorganisir dengan baik di otak) selalu berintegrasi dengan lingkungannya melalui asimilasi dan akomodasi. Jika asimilasi dan akomodasi terjadi dengan bebas dengan lingkungannya (bebas konflik), maka struktur kognitif dikatakan dalam keadaan ekuiblirium dengan lingkungannya, namun jika hal ini tidak terjadi pada seseorang, maka seseorang tersebut dikatakan pada keadaan yang tidak seimbang (disekuilibrium), lalu Dia akan mencari keseimbangan yang baru dengan lingkungannya dengan meminta bantuan dengan teman yang tidak terjadi disequblirium atau diberi scaffolding oleh guru. Disekuiblirium kognitif atau konflik kognitif perlu dikondisikan agar terjadi suatu equiblirium pada tingkat yang lebih tinggi daripada equiblirium sebelumnya khususnya untuk kemampuan komunikasi matematis siswa.

Berdasarkan pada uraian latar belakang masalah, maka yang menjadi rumusan masalah dalam penelitian ini adalah, apakah peningkatan kemampuan komunikasi matematis siswa yang menerapkan pembelajaran konflik kognitif lebih baik dibandingkan dengan siswa yang mendapat pembelajaran biasa?, apakah terdapat perbedaan peningkatan kemampuan komunikasi matematis antara siswa yang menerapkan pembelajaran konflik kognitif dengan siswa yang mendapat pembelajaran biasa bila ditinjau dari kategori pengetahuan awal matematika (tinggi dan rendah)?.

\section{METODE PENELITIAN}

Penelitian ini merupakan penelitian quasi experiment atau eksperimen semu yang terdiri dari dua kelompok penelitian yaitu kelas eksperimen (kelas perlakuan), kelas ini merupakan kelompok siswa yang pembelajarannya menerapkan pembelajaran konflik kognitif dan kelompok kontrol (kelas pembanding) adalah kelompok siswa yang pembelajarannya tidak menerapkan pembelajaran konflik kognitif (biasa). Pertimbangan penggunaan desain penelitian ini adalah bahwa kelas yang ada sudah terbentuk sebelumnya, dan pembentukan kelas baru akan menyebabkan kekacauan jadwal pelajaran serta mengganggu efektivitas pembelajaran di sekolah. Sehingga tidak dilakukan lagi pengelompokkan secara acak.

Dengan demikian untuk mengetahui adanya perbedaan kemampuan komunikasi matematis siswa terhadap pembelajaran matematika dilakukan penelitian dengan desain kelompok kontrol non-ekuivalen (Ruseffendi, 2005: 52) berikut: 
Kelas Eksperimen

Kelas Kontrol

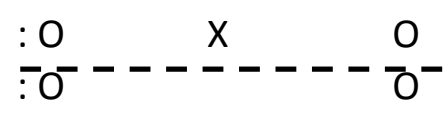

Keterangan:

O : Pre-test atau Post-test kemampuan komunikasi

$\mathrm{X} \quad$ : Pembelajaran konflik kognitif

- - - : Subjek tidak dikelompokkan secara acak

Untuk melihat secara lebih mendalam pengaruh implementasi pembelajaran konflik kognitif terhadap kemampuan komunikasi matematis siswa maka dalam penelitian ini dilibatkan faktor kategori pengetahuan awal matematis siswa (tinggi dan rendah).

Penelitian ini dilakukan di salah satu Sekolah Menengah Atas Swata di Bandung. Populasi dalam penelitian ini adalah seluruh siswa kelas XIPA salah satu Sekolah Menengah Atas Swata di Bandung semester genap pada tahun ajaran 2013/2014.

Pengambilan sampel dilakukan dengan teknik purposive sampling, yaitu teknik penentuan sampel dengan pertimbangan tertentu (Sugiyono, 2008). Tujuan dilakukan pengambilan sampel dengan teknik ini adalah agar penelitian dapat dilaksanakan secara efektif dan efisien terutama dalam hal pengawasan, kondisi subyek penelitian, waktu penelitian yang ditetapkan, kondisi tempat penelitian serta prosedur perijinan. Berdasarkan teknik tersebut diperoleh kelas X IPA-B sebagai kelas eksperimen (kelas yang memperoleh pembelajaran konflik kognitif) dan kelas $X$ IPA-A sebagai kelas kontrol (kelas yang memperoleh pembelajaran biasa) dengan penimbang Wakil Kepala Sekolah dan guru.

\section{HASIL PENELITIAN DAN PEMBAHASAN}

Data kemampuan komunikasi matematis diperoleh melalui pre-test dan post-test, dan $\mathrm{N}$-gain. Berikut ini merupakan deskripsi pre-test, post-test, dan $\mathrm{N}$-gain pada kelas eksperimen dan kelas kontrol.

Tabel 1. Statistik Deskriptif Kemampuan Komunikasi Matematis

\begin{tabular}{ccccccccc}
\hline \multirow{2}{*}{ Nilai } & \multicolumn{4}{c}{ Eksperimen } & \multicolumn{4}{c}{ Kontrol } \\
\cline { 2 - 9 } & $\mathbf{N}$ & $\overline{\boldsymbol{x}}$ & SD & $\%$ & $\mathbf{N}$ & $\overline{\boldsymbol{x}}$ & SD & $\%$ \\
\hline Pre-test & 32 & 1,97 & 0,59 & 13,13 & 31 & 1,77 & 1,15 & 11,83 \\
Post-test & 32 & 4,72 & 1,49 & 31,46 & 31 & 3,74 & 1,32 & 24,95 \\
N-gain & 32 & 0,21 & 0,10 & & 31 & 0,15 & 0,06 & \\
\hline
\end{tabular}

Skor Maksimum Ideal = 15

Berdasarkan Tabel 1 di atas, diperoleh rataan pre-test untuk kelas eksperimen sebesar 1,97 dan untuk kelas kontrol sebesar 1,77. Rataan pre-test kedua kelas relatif sama sebelum diberikan perlakuan. Persentase skor diperoleh dari hasil bagi skor rataan dengan skor ideal dikali $100 \%$. Rataan skor post-test kemampuan komunikasi pada kelas eksperimen adalah 4,72 atau 6,51\% lebih tinggi daripada kelas kontrol dengan rataan post-test sebesar 3,74. Rataan $\mathrm{N}$-gain kemampuan komunikasi pada kelas eksperimen adalah 0,21 dengan klasifikasi peningkatan rendah dan untuk kelas kontrol sebesar 0,15 dengan klasifikasi peningkatan rendah. Berikut secara ringkas disajikan perbandingan rataan skor pre-test, post-test, dan $\mathrm{N}$-gain kemampuan kumunikasi matematis siswa. 
Tabel 2. Rataan Skor Pre-test, Post-test, dan N-gain Kemampuan Komunikasi Matematis Siswa

\begin{tabular}{cccc}
\hline Kelas & Pre-test & Post-test & N-gain \\
\hline Eksperimen & 1,97 & 4,72 & 0,21 \\
Kontrol & 1,77 & 3,74 & 0,15 \\
\hline
\end{tabular}

Untuk lebih jelasnya Tabel 2 di atas dapat dibuat diagram perbandingan rataan skor pre-test dan post-test sebagai berikut.

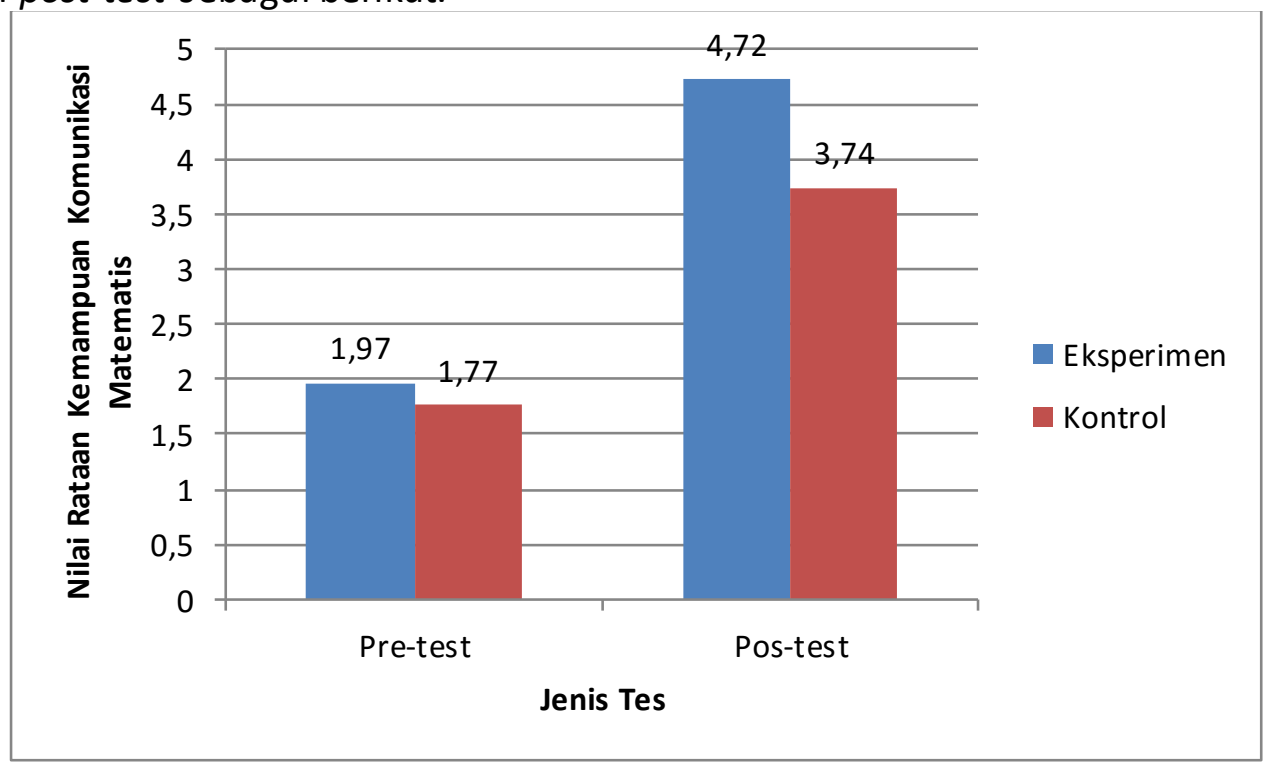

Gambar 2. Perbandingan Nilai Rataan Skor Pre-test dan Post-test Kemampuan Komunikasi Matematis

Dari Gambar 2 di atas tampak bahwa rataan pre-test kelas eksperimen dan kelas kontrol tidak jauh berbeda, nilai rataan kelas eksperimen 1,97 sedangkan kelas kontrol 1,77 yang menunjukkan bahwa kemampuan awal kedua kelas relatif sama sebelum diberikan perlakuan. Sedangkan untuk rataan post-test kelas eksperimen yang menerapkan pembelajaran konflik kognitif menunjukkan hasil yang lebih baik dengan nilai rataan 4,72 dibandingkan kelas kontrol yang mendapatkan pembelajaran biasa dengan nilai rataan 3,74. Berdasarkan data di atas menunjukkan bahwa terjadi peningkatan skor kemampuan komunikasi matematis siswa setelah pembelajaran dilaksanakan.

Analisis skor $\mathrm{N}$-gain kemampuan komunikasi matematis menggunakan data gain ternormalisasi, data gain ternormalisasi juga menunjukkan klasifikasi peningkatan skor siswa yang dibandingkan dengan skor maksimal idealnya. Rataan $\mathrm{N}$-gain menggambarkan peningkatan kemampuan komunikasi matematis siswa yang menerapkan pembelajaran konflik kognitif maupun yang mendapat pembelajaran biasa.

Rangkuman rataan $\mathrm{N}$-gain kemampuan komunikasi matematis siswa pada kelas eksperimen dan kelas kontrol disajikan dalam Tabel berikut. 
Tabel 3. Rataan dan Klasifikasi N-gain Kemampuan Komunikasi Matematis

\begin{tabular}{ccc}
\hline Kelas & Rataan $\boldsymbol{N}$-gain & Klasifikasi \\
\hline Eksperimen & 0,21 & Rendah \\
Kontrol & 0,15 & Rendah \\
\hline
\end{tabular}

Dari Tabel 3 di atas dapat dibuat diagram perbandingan rataan skor $\mathrm{N}$-gain kemampuan komunikasi matematis siswa pada kelas eksperimen dan kelas kontrol.

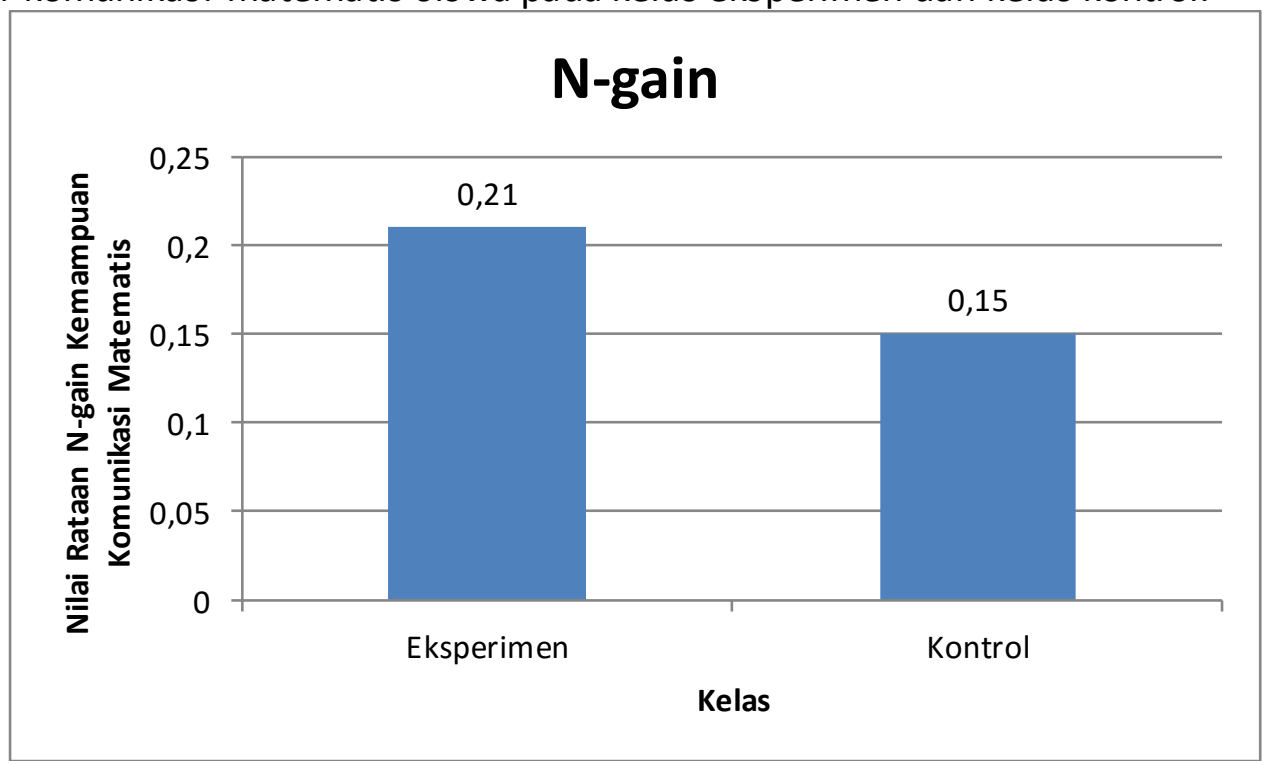

Gambar 3. Perbandingan Nilai Rataan Skor N-gain Kemampuan Komunikasi Matematis

Dari Gambar 3 di atas terlihat bahwa siswa yang menerapkan pembelajaran konflik kognitif (kelas eksperimen) memiliki rataan skor $N$-gain 0,21 sedangkan siswa yang mendapatkan pembelajaran biasa (kelas kontrol) memiliki rataan skor $\mathrm{N}$-gain 0,15.

$\mathrm{Hal}$ ini menunjukkan bahwa peningkatan kemampuan komunikasi matematis siswa kelas eksperimen lebih baik atau lebih tinggi daripada kelas kontrol. Namun untuk menyakinkan apakah benar peningkatan kemampuan komunikasi matematis siswa yang menerapkan pembelajaran konflik kognitif lebih baik daripada siswa yang mendapatkan pembelajaran biasa perlu dilakukan uji statistik lanjutan.

Berdasarkan hasil uji normalitas yang telah dilakukan sebelumnya didapat kesimpulan bahwa skor $\mathrm{N}$-gain kelas eksperimen dan kelas kontrol berdistribusi normal, serta skor $\mathrm{N}$ gain kemampuan komunikasi matematis siswa kelas eksperimen dan kelas kontrol berasal dari varian yang tidak homogen. Untuk membuktikan bahwa skor $N$-gain kemampuan komunikasi matematis siswa kelas eksperimen lebih baik daripada kelas kontrol dilakukan uji perbedaan rataan skor $\mathrm{N}$-gain dengan menggunakan uji independent sample $t$-test dengan asumsi varian tidak sama (uji t'). 
Berikut rangkuman hasil uji perbedaan rataan skor $N$-gain pada taraf signifikansi $\alpha=$ 0,05 .

Tabel 4. Hasil Uji Perbedaan Rataan Skor N-gain Kemampuan Komunikasi Matematis

\begin{tabular}{cccc}
\hline \multicolumn{2}{c}{ t-test for Equality of Means } & \multirow{2}{*}{ Keterangan } & \multirow{2}{*}{ Kesimpulan } \\
\hline $\mathbf{T}$ & Sig. (1-tailed) & & \\
\hline 2,955 & 0,0025 & Ho Ditolak & Terdapat Perbedaan \\
\hline
\end{tabular}

Berdasarkan hasil di atas didapat nilai Sig. (1-tailed) yaitu 0,0025 $<\alpha=0,05$. Hal ini menunjukkan bahwa $\mathrm{H}_{0}$ ditolak, artinya peningkatan kemampuan komunikasi matematis siswa kelas eksperimen lebih baik daripada siswa kelas kontrol, dengan demikian terbukti bahwa hipotesis yang menyatakan bahwa peningkatan kemampuan komunikasi matematis siswa yang menerapkan pembelajaran konflik kognitif lebih baik daripada siswa yang mendapatkan pembelajaran biasa.

Deskripsi rataan $\mathrm{N}$-gain dan standar deviasi data kemampuan komunikasi berdasarkan pembelajaran dan kategori PAM pada Tabel 5.

Tabel 5. Deskripsi Data Kemampuan Komunikasi Berdasarkan PAM dan Pembelajaran

\begin{tabular}{cccccc}
\hline Kategori & \multirow{2}{*}{ PAM } & Statistik & \multicolumn{4}{c}{$\boldsymbol{N}$-gain } \\
\cline { 3 - 6 } Tinggi & Rataan & 0,24 & 0,16 & & 0,20 \\
& Std. Deviasi & 0,10 & 0,07 & 0,08 & 0,10 \\
& Jml. Siswa & 17 & 16 & & 33 \\
\multirow{2}{*}{ Rendah } & Rataan & 0,17 & 0,14 & & 0,16 \\
& Std. Deviasi & 0,09 & 0,06 & 0,03 & 0,08 \\
& Jml. Siswa & 15 & 15 & & 30 \\
& Rataan & 0,21 & 0,15 & & 0,18 \\
Gabungan & Std. Deviasi & 0,10 & 0,06 & 0,06 & 0,09 \\
& Jml. Siswa & 32 & 31 & & 63 \\
\hline
\end{tabular}

Berdasarkan data pada tabel di atas, dapat dibuat diagram perbandingan rataan $N$ gain kemampuan komunikasi matematis siswa berdasarkan pembelajaran dan PAM, seperti yang dimuat pada Gambar 4 di bawah ini. 


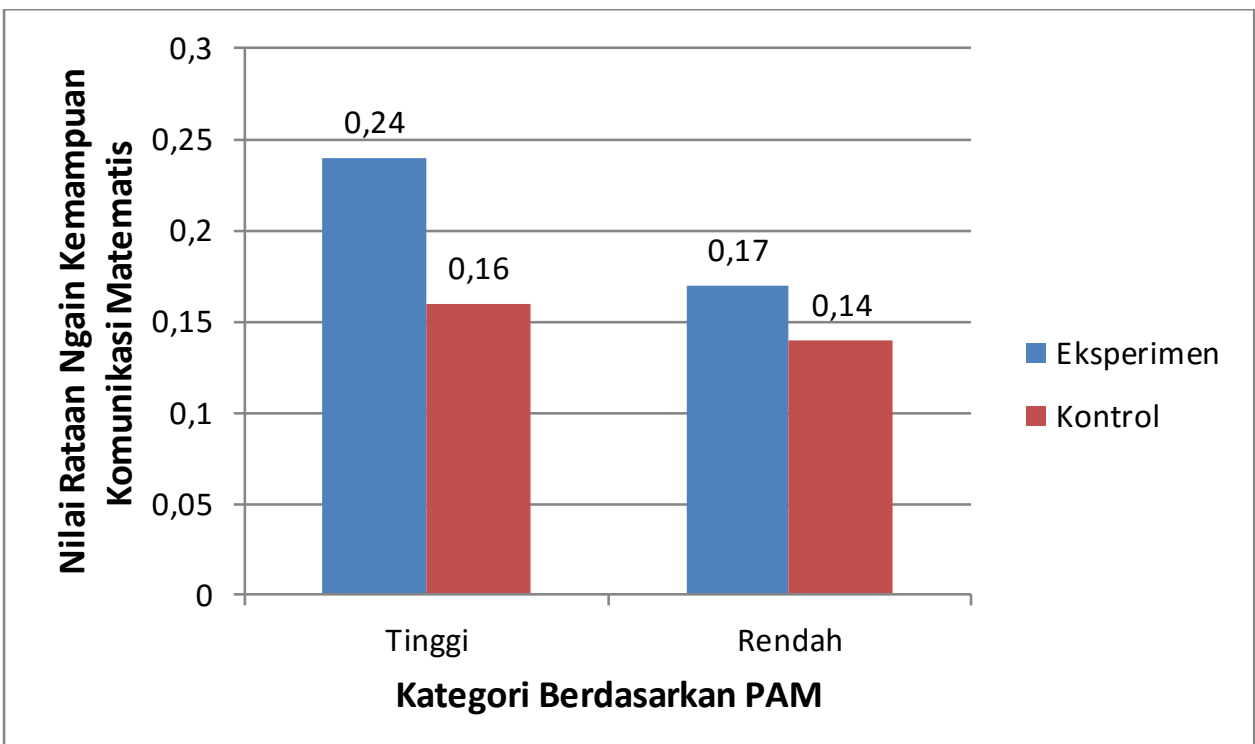

Gambar 4. Perbandingan Nilai Rataan N-gain Kemampuan Komunikasi Berdasarkan Pembelajaran dan Kategori PAM

Diperoleh informasi bahwa pada kategori PAM siswa berkemampuan tinggi dan rendah siswa yang menerapkan pembelajaran konflik kognitif memperoleh peningkatan yang lebih tinggi dibandingkan dengan siswa yang mendapatkan pembelajaran biasa. Hal ini dapat dilihat dari perbedaan rataan $\mathrm{N}$-gain kemampuan komunikasi matematis siswa pada setiap kategori PAM, untuk kategori PAM siswa berkemampuan tinggi perbedaannya sebesar 0,08 dan kategori PAM siswa berkemampuan rendah perbedaanya sebesar 0,03.

Berdasarkan hasil uji normalitas yang telah dilakukan sebelumnya didapat kesimpulan bahwa skor $\mathrm{N}$-gain kelas eksperimen dan kelas kontrol untuk semua kategori berdistribusi normal. Sedangkan untuk uji homogenitas menunjukkan bahwa skor $\mathrm{N}$-gain kemampuan komunikasi matematis siswa untuk kategori pengetahuan awal matematika tinggi berasal dari varian yang homogen, akan tetapi untuk skor kemampuan komunikasi matematis siswa kategori rendah tidak berasal dari varian yang homogen.

Untuk membuktikan ada tidaknya perbedaan peningkatan kemampuan komunikasi matematis siswa untuk masing-masing kategori pengetahuan awal matematika siswa digunakan uji independent sample t-test dengan asumsi varian sama (uji t) dan asumsi varian tidak sama (uji t').

Tabel 6. Hasil Uji Perbedaan Rataan Skor N-gain KKM Berdasarkan

PAM dan Pembelajaran

\begin{tabular}{cccccc}
\hline $\begin{array}{c}\text { Peng. Awal } \\
\text { Matematika }\end{array}$ & Pembelajaran & $\begin{array}{c}\text { Perbandingan } \\
\text { Rataan }\end{array}$ & Statistic & Sig. & Kesimpulan \\
\hline Tinggi & PK : PB & $0,25: 0,16$ & 2,821 & 0,008 & $\mathrm{H}_{0}$ Ditolak \\
Rendah & PK : PB & $0,18: 0,14$ & 1,287 & 0,211 & $\mathrm{H}_{0}$ Diterima \\
\hline
\end{tabular}

Berdasarkan Tabel 6 di atas dapat disimpulkan bahwa untuk kategori pengetahuan awal matematika siswa kategori tinggi, peningkatan kemampuan komunikasi matematis siswa yang menerapkan pembelajaran konflik kognitif secara signifikan terdapat perbedaan 
dengan siswa yang mendapatkan pembelajaran biasa. Kategori pengetahuan awal matematika siswa rendah, peningkatan kemampuan komunikasi matematis siswa yang menerapkan pembelajaran konflik kognitif secara signifikan tidak terdapat perbedaan dengan siswa yang mendapatkan pembelajaran biasa.

Untuk mengetahui ada tidaknya interaksi antara pembelajaran dan pengetahuan awal matematika terhadap peningkatan kemampuan komunikasi matematis siswa dilakukan uji Anova dua jalur. Sebelum melakukan uji Anova dua jalur, terlebih dahulu dilakukan uji normalitas. Hasil perhitungan uji normalitas, menunjukkan bahwa data peningkatan kemampuan pemecahan masalah matematis siswa berdasarkan pembelajaran dan kategori pengetahuan awal matematis berdistribusi normal. Hasil perhitungan uji Anova dua jalur selengkapnya disajikan pada Lampiran C. Ringkasan hasil uji tersebut disajikan pada Tabel 7

Tabel 7. Hasil Uji Anova Dua Jalur Peningkatan Kemampuan Komunikasi Matematis Berdasarkan PAM dan Pembelajaran

\begin{tabular}{lcccc}
\hline \multicolumn{1}{c}{ Sumber } & df & $\begin{array}{c}\text { Mean } \\
\text { Square }\end{array}$ & $\boldsymbol{F}$ & Sig. \\
\hline Corrected Model & 3 & 0,035 & 5,028 & 0,004 \\
Kategori PAM & 1 & 0,030 & 4,356 & 0,041 \\
$\begin{array}{l}\text { Pembelajaran } \\
\text { Kategrori }\end{array}$ & 1 & 0,060 & 8,610 & 0,005 \\
$\begin{array}{l}\text { PAM* Pembelajaran } \\
\text { (interaksi) }\end{array}$ & 1 & 0,010 & 1,489 & 0,227 \\
\hline Error & 59 & 0,007 & & \\
\hline Total & 63 & & & \\
\hline
\end{tabular}

Berdasarkan Tabel 7 di atas dapat disimpulkan bahwa faktor kategori pengetahuan awal matematis (PAM) siswa memberikan pengaruh yang signifikan terhadap peningkatan kemampuan komunikasi matematis siswa. Hal ini terlihat dari nilai $\mathrm{F}$ yang diperoleh dengan nilai signifikansi $0,041<\alpha=0,05$. Faktor pembelajaran (pembelajaran konflik kognitif dan biasa) juga memberikan pengaruh yang signifikan terhadap peningkatan kemampuan komunikasi matematis siswa. Hal ini terlihat dari nilai $F$ yaitu 8,610 dan mempunyai nilai signifikansi yaitu $0,005<\alpha=0,05$.

Berdasarkan hasil uji Anova dua jalur pada Tabel 7 diperoleh nilai $\mathrm{F}$ untuk interaksi adalah 1,489 dengan (sig.) $=0,227 \geq 0,05$ berarti tidak terdapat interaksi antara pembelajaran (konflik kognitif dan biasa) dan pengetahuan awal matematika (tinggi dan rendah) terhadap peningkatan kemampuan pemecahan masalah matematis siswa. Diagram tidak ada interaksi tersebut dapat dilihat secara grafis pada Gambar 4.8 berikut ini. 


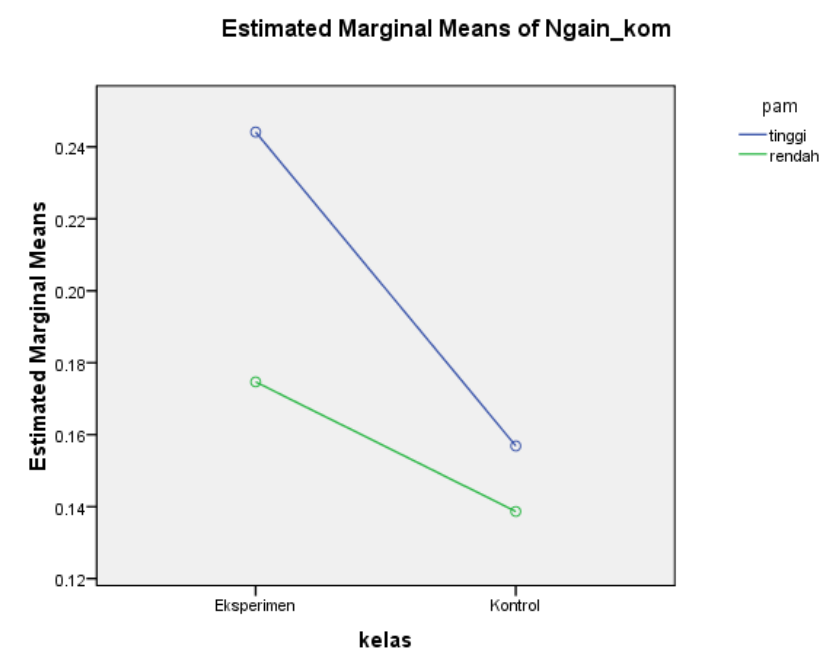

Gambar 6. Interaksi antara Pembelajaran dan Kategori PAM terhadap Peningkatan Kemampuan Komunikasi Matematis

\section{SIMPULAN DAN SARAN}

Hasil penelitian menunjukkan bahwa perkembangan kemampuan komunikasi matematis siswa yang menerapkan pembelajaran konflik kognitif secara signifikan lebih baik dibandingkan dengan siswa yang memperoleh pembelajaran biasa. Hal ini ditunjukkan dengan skor $\mathrm{N}$-gain siswa yang menerapkan pembelajaran konflik kognitif sebesar 0,21 (kategori rendah), lebih tinggi daripada siswa yang memperoleh pembelajaran biasa sebesar 0,15 (kategori rendah).

Hasil tersebut memberikan gambaran bahwa pembelajaran konflik kognitif dapat mengembangkan kemampuan komunikasi matematis siswa. Hal ini terjadi karena dalam pembelajaran konflik kognitif siswa diberikan kesempatan untuk mampu mengomunikasikan masalah ke dalam ide matematika.

Pembelajaran konflik kognitif dapat meningkatkan kemampuan komunikasi matematis siswa, akan tetapi penelitian ini masih menyisakan permasalahan rendahnya nilai kemampuan komunikasi matematis. Rendahnya kemampuan komunikasi matematis disebabkan oleh beberapa faktor.

Faktor yang mungkin menyebabkan rendahnya kemampuan komunikasi matematis siswa adalah tingkat kesulitan soal yang diberikan. Terhadap soal kemampuan komunikasi matematis yang diberikan kepada siswa, guru kelas menyatakan bahwa soal-soal yang diberikan dirasa terlalu sukar untuk diselesaikan anak didiknya. Namun, dari hasil uji coba soal diperoleh keterangan bahwa semua soal tergolong sedang. Hal ini terjadi, mungkin karena tingkat kemampuan siswa pada kelas uji coba lebih tinggi dari siswa pada kelas penelitian. Faktor lain yang tidak kalah pentingnya adalah pengetahuan awal matematika siswa (materi SMP) yang masih rendah. Hal ini juga diakui oleh guru matematika pengampu, hampir semua siswa pengetahuan awal matematikanya masih sangat rendah. 


\section{DAFTAR PUSTAKA}

Darhim. (2004). Pengaruh Pembelajaran Matematika Kontekstual Terhadap Hasil Belajar dan Sikap Siswa Sekolah Dasar Kelas Awal Matematika. Disertasi Doktor pada PPS Universitas Pendidikan Indonesia Bandung: Tidak Diterbitkan.

Depdiknas. (2006). Panduan Penyusunan Kurikulum Tingkat Satuan Pendidikan. Jakarta: Badan Standar Nasional Pendidikan.

Brenner, M.E. (1998). "Development of Mathematical Communication in Problem Solving Groups by Language Minority Students". Bilingual Research Journal. 22, (2), 103-128.

Herman, T. (2005). Pembelajaran Berbasis Masalah Untuk Meningkatkan Kemampuan Berpikir Matematis Tingkat Tinggi Siswa Sekolah SMP. Disertasi Doktor pada SPs Univeritas Pendidikan Indonesia Bandung: Tidak diterbitkan.

Ismaimuza, D. (2010). Kemampuan Berfikir Kritis dan Kreatif Matematis Siswa SMP Melalui Pembelajaran Berbasis Masalah dengan trategi Konflik Kognitif. Disertasi Doktor pada SPs Univeritas Pendidikan Indonesia Bandung: Tidak diterbitkan.

Ismaimuza, D. (2010). Pengaruh Pembelajaran Berbasis Masalah dengan Strategi Konflik Kognitif Terhadap Kemampuan Berfikir Kritis Matematis dan Sikap Siswa SMP. Jurnal Pendidikan Matematika Volume 4 Nomor 1, 1-10.

Kosasih, U., \& Mulyana, T. (2013). Meningkatkan Kemampuan Berfikir Kreatif dan Komunikasi Matematis melalui Pembelajaran dengan Pendekatan Open-Ended. Jurnal Pendidikan Sigma Didaktika Volume 1 Nomor 2, 126-133.

Lee, G., \& Kwon, J. (2001). What Do We Know about Students' Cognitive Conflict in Science Classroom: A theoritical Model of Cognitive Conflict Process [Online]. Tersedia: http://www.eric.ed.gov/ERICWebPortal/search/detailmini.jsp? nfpb=true\& \&ERICE xtSearch_SearchValue 0=ED472903\&ERICExtSearch_SearchType $0=$ no\&accno=ED47 2903 [20 Mei 2013].

Mahmudi, A. (2009). "Komunikasi dalam Pembelajaran Matematika". Jurnal MIPMIPA UNHALU. 8, (1), 1-9.

Permana, Y. (2009). Mengembangkan Kemampuan Pemahaman, Komunikasi, dan Disposisi Matematis Siswa Sekolah Menengah Atas Melalui ModelEliciting Activities. Disertasi Pada SPS UPI. Bandung : Tidak Diterbitkan.

Prabawanto, S. (2013). Peningkatan Kemampuan Pemecahan Masalah, komunikasi dan Self Efficacy Matematis Mahasiswa Melalui Pembelajaran Dengan Pendekatan Metacognitive Scaffolding. Disertasi tidak diterbitkan. Bandung: Disertasi Pendidikan Universitas Pendidikan Indonesia.

Pusat Bahasa. (2008). Kamus Bahasa Indonesia. Jakarta : Departemen Pendidikan Nasional. Ruseffendi, H. E. T. (2005). Dasar-dasar Penelitian Pendidikan dan Bidang Non-Eksakta Lainnya. Bandung: Tarsito.

Sabandar, J (2005). Pendekatan Konflik Kognitif pada Pembelajaran Matematika dalam Upaya Mengembangkan Kemampuan Berfikir Kritis dan Kreatif. National Seminar On Operation Research, FMIPA UNPAD.

Sugiyono. (2008). Metode Penelitian Kuantitatif, Kualitatif dan R\&D. Bandung: Penerbit Alfabeta Bandung.Sumarmo,U. (1993). Peranan Kemampuan Logic dan Kegiatan 
Belajar Terhadap kemampuan Pemecahan Masalah Matematika Pada siswa SMA di Kodya Bandung. Laporan Penelitian FPMIPA IKIP Bandung : Tidak diterbitkan.

Sumarmo, U. (2012). Pendidikan Karakter Serta pengembangan Berfikir dan Disposisi Matematik dalam Pembelajaran Matematika. Makalah disajikan dalam Seminar Pendidikan Matematika di NTT tanggal 25 Februari 2012.

Suryadi, D. (2005). Penggunaan Pendekatan Pembelajaran Tidak Langsung serta Pendekatan Gabungan Langsung dan Tidak Langsung dalam Rangka Meningkatkan Kemampuan Tingkat Tinggi Siswa SLTP. Disertasi Doktor pada PPS Universitas Pendidikan Indonesia Bandung: Tidak Diterbitkan.

Wahyudin. (1999). Kemampuan Guru Matematika, Calon Guru Matematika dan Siswa dalam Mata Pelajaran Matematika. Disertasi Doktor pada PPS IKIP Bandung: Tidak Diterbitkan.

Wardhani, S., \& Rumiati. (2011). Instrumen Penilaian Hasil Belajar Matematika SMP; Belajar dari PISA dan TIMSS. Yogyakarta: Kemdiknas, P4TK Matematika. 